\title{
Haloperidol, a Dopaminergic Antagonist: Somatostatin-Like Inhibition of Glucagon and Insulin Release from the Isolated, Perfused Canine Pancreas*
}

\author{
K. Hermansen \\ Second University Clinic of Internal Medicine, Kommunehospitalet, Aarhus, Denmark
}

\begin{abstract}
Summary. The effect of haloperidol, a dopaminergic antagonist, on insulin and glucagon secretion was investigated using the isolated, perfused canine pancreas. Haloperidol at $4 \times 10^{-7}$ to $10^{-5} \mathrm{~mol} / \mathrm{l}$ caused a dose-dependent inhibition of glucagon release both at low $(25 \mathrm{mg} / 100 \mathrm{ml})$ and high glucose concentrations $(150 \mathrm{mg} / 100 \mathrm{ml})$. At the low glucose concentration insulin release was already maximally suppressed. At the high glucose concentration haloperidol $\left(4 \times 10^{-7}\right.$ to $\left.10^{-5} \mathrm{~mol} / \mathrm{l}\right)$ also caused a dosedependent inhibition of insulin release. Haloperidol $\left(10^{-5} \mathrm{~mol} / \mathrm{l}\right)$ inhibited dramatically pancreatic $\mathrm{A}$ and $B$ cell responses to isoproterenol $(2 \mathrm{ng} / \mathrm{ml})$, acetylcholine $(1 \mu \mathrm{mol} / \mathrm{l})$ and arginine $(5 \mathrm{mmol} / \mathrm{l})$. The inhibitory effect of haloperidol on both glucagon and insulin release could be eliminated by increasing perfusate calcium concentration from 1.3 to $8.8 \mathrm{mmol} / \mathrm{l}$. These findings suggested that haloperidol blocks glucagon and insulin release in a somatostatin-like manner by affecting a fundamental step of the stimulus-secretion coupling, probably by interfering with calcium handling of the pancreatic $\mathrm{A}$ and $\mathrm{B}$ cells.
\end{abstract}

Key words: Isolated, perfused canine pancreas, haloperidol, acetylcholine, isoproterenol, arginine, calcium, somatostatin-like inhibition, insulin secretion, glucagon secretion.

Falck and Hellman $[1,2]$ have demonstrated that in many species the endocrine pancreatic cells contain monoamines, particularly serotonin and dopamine $[3,4]$. The physiological significance of these monoamines stored within the islet cells is unknown.

\footnotetext{
* Presented in part at the $13^{\text {th }}$ Annual Meeting of the European Association for the Study of Diabetes, Geneva, Switzerland, September 1977
}

During investigations on monoaminergic mechanisms in pancreatic islets we employed the dopaminergic antagonist haloperidol, which is purported to be a specific dopamine receptor blocking agent in tissues such as brain [5], exocrine pancreas [6] and renal and mesenteric vessels [7]. Using the isolated, perfused canine pancreas it was noted that this dopaminergic antagonist inhibited release of both glucagon and insulin.

The purpose of the present study was to investigate further the effect of haloperidol on insulin and glucagon secretion from the isolated, perfused canine pancreas in order to elucidate the mechanisms by which this substance produces its bihormonal inhibitory actions.

\section{Material and Methods}

Mongrel dogs, fasted overnight, weighing $18-25 \mathrm{~kg}$ were used as pancreas donors. The technique for isolation of the canine pancreas and the perfusion system have been described in detail by Iversen $[8,9]$. In brief, the preparation consisted of the pancreas and the proximal $10 \mathrm{~cm}$ of the attached duodenum. A nonrecirculating medium consisting of a Krebs Ringer bicarbonate buffer containing dextran $40 \mathrm{~g} / \mathrm{l}$ (MW 75,000), $2 \mathrm{~g} / \mathrm{l}$ bovine albumin, glutamate, fumarate and pyruvate, each at a concentration of 5 $\mathrm{mmol} / \mathrm{l}$ was introduced through the splenic and the coeliac arteries, and the total portal effluent was collected every $1 \mathrm{~min}$. Oxygenation of the Krebs-Ringer bicarbonate buffer was achieved by means of a rotating roller screen in an atmosphere of 94.4 per cent $\mathrm{O}_{2}$ and 5.6 per cent $\mathrm{CO}_{2}$. Oxygen consumption has been measured in some experiments and was found to be constant during the perfusions around $0.005 \mathrm{ml} / \mathrm{min} / \mathrm{g}$ tissue. $\mathrm{PH}$ of the perfusion fluid was constant at 7.4 throughout the experiments.

The perfusion pressure was $30-40 \mathrm{mmHg}$ and the perfusion flow was $18-20 \mathrm{ml} / \mathrm{min}$. Both parameters were constantly monitored and remained unchanged. The basic perfusion medium was composed with a calcium concentration of $1.3 \mathrm{mmol} / \mathrm{l} . \mathrm{CaCl}_{2}$ was added to result in final concentrations of 6.3 and $8.8 \mathrm{mmol} / \mathrm{l}$. The chemicals employed and their sources were as follows: Haloperidol (4-[-4- (p-Chlorophenyl) -4- hydroxypiperidino] -4fluorobutyrophenone) (a gift from Janssen Pharma, Copenhagen, 


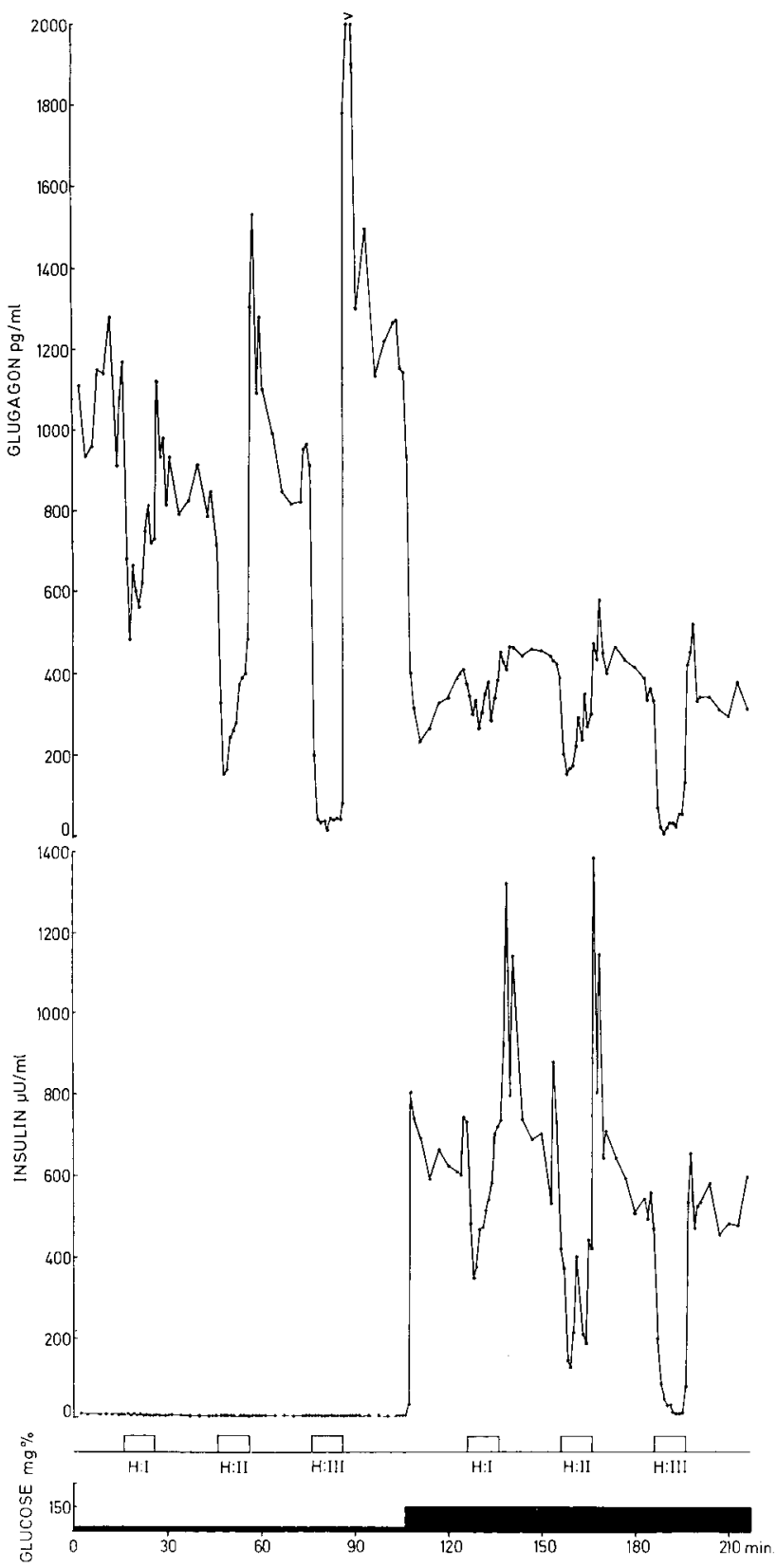

Fig. 1. Effect of Haloperidol at concentrations of $4 \times 10^{-7} \mathrm{~mol} / \mathrm{l}$ (H I), $2 \times 10^{-6} \mathrm{~mol} / 1$ (H II) and $10^{-5} \mathrm{~mol} / 1$ (H III) upon the secretion of glucagon and insulin during perfusion with low $(25 \mathrm{mg} / 100 \mathrm{ml})$ and high $(150 \mathrm{mg} / 100 \mathrm{ml})$ glucose concentrations in a representative experiment. The calcium concentration was $1.3 \mathrm{mmol} / 1$

Denmark); 1-arginine hydrochloride (Sigma Chemical Comp., St. Louis, U.S.A.); 1-isoproterenol (Sigma Chemical Comp., St. Louis, U.S.A.); and acetylcholine (Sigma Chemical Comp., St. Louis, U.S.A.).

Glucagon and insulin were measured by a single antibody radioimmunoassay (10). In the glucagon assay an antiserum highly specific to pancreatic glucagon (K 964, a gift from Lise Heding, NOVO Research Lab., Copenhagen) was used. The sensitivity of the glucagon assay allowed differences in concentration of $10 \mathrm{pg}$ / $\mathrm{ml}$ to be distinguished with 95 per cent confidence. The separation of free from bound hormone was performed by wick-chromatography [10]. At the concentrations tested Haloperidol did not interfere in the radioimmunoassay.

Statistical analysis were made by Student's t test for paired comparisons.

\section{Results}

1. Effect of Haloperidol upon the Secretion of Insulin and Glucagon at Low $(25 \mathrm{mg} / 100 \mathrm{ml})$ and at High $(150 \mathrm{mg} / 100 \mathrm{ml})$ Concentrations of Glucose

In order to determine the effects of Haloperidol insulin and glucagon release in response to low $(25 \mathrm{mg} /$ $100 \mathrm{ml})$ and high $(150 \mathrm{mg} / 100 \mathrm{ml})$ glucose concentrations was studied during sequential $10 \mathrm{~min}$ infusions of Haloperidol at various concentrations. A representative experiment is shown in Figure 1. In the basal state with a calcium concentration of $1.3 \mathrm{mmol} / 1$ and a glucose concentration of $25 \mathrm{mg} /$ $100 \mathrm{ml}$ insulin secretion was unmeasurable, while glucagon release was high. Within 1-2 min of introduction of Haloperidol at 3 different concentrations $\left(4 \times 10^{-7}, 2 \times 10^{-6}\right.$ and $\left.10^{-5} \mathrm{~mol} / 1\right)$, glucagon release was inhibited in a dose-dependent manner. At this low glucose concentration no turther inhibition of insulin release could be detected. When the glucose concentration in the perfusing medium was increased from 25 to $150 \mathrm{mg} / 100 \mathrm{ml}$ insulin release followed the typical biphasic response pattern and glucagon release was suppressed as expected. Infusions of Haloperidol for $10 \mathrm{~min}$ at the same concentrations as used before now caused a dose-dependent inhibition of both insulin and glucagon release. Upon removal of Haloperidol from the perfusate the hormone secretion after a short off-response attained preinhibition values. Data from 3 experiments demonstrating the clearcut dose-dependent inhibition of Haloperidol on insulin and glucagon secretion are shown in Figure 2. The relative inhibitory effect of Haloperidol on glucagon secretion is the same at low and high glucose concentrations. Identical results were obtained when Haloperidol was infused in decreasing concentrations.

\section{Effect of Haloperidol upon Insulin and Glucagon} Responses to Arginine, Isoproterenol, and Acetylcholine

The purpose of the following experiments was to determine whether Haloperidol inhibited pancreatic $\mathrm{A}$ and $\mathrm{B}$ cell responses to stimuli such as arginine $(5 \mathrm{mmol} / \mathrm{l})$, isoproterenol $(2 \mathrm{ng} / \mathrm{ml})$, and acetylcholine $(1 \mu \mathrm{mol} / \mathrm{l})$. These experiments were carried out with a glucose concentration of $75 \mathrm{mg} / 100 \mathrm{ml}$ 

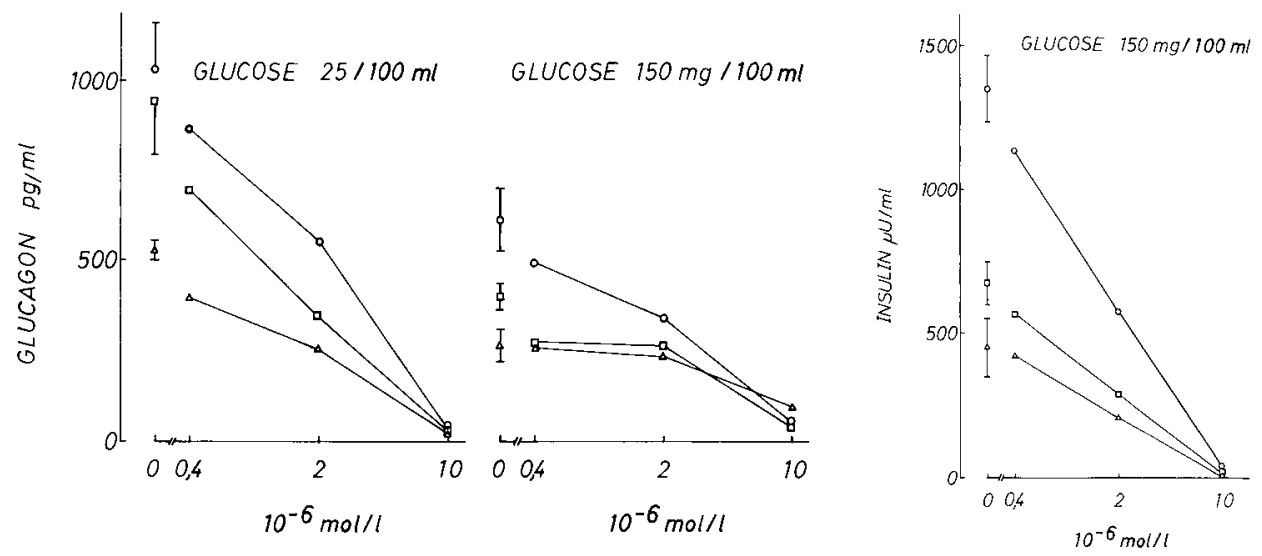

Fig. 2. Dose-dependent inhibition of insulin and glucagon release with Haloperidol in three perfusion experiments indicated by three different symbols. The mean $\pm \mathrm{SD}$ of the preinfusion levels from each experiment is shown above the 'zero point' on the logarithmic abscissa. The symbols on the curves represent mean values of the 5 last minutes hormone release during addition of various concentrations of Haloperidol

and at a calcium concentration of $1.3 \mathrm{mmol} / \mathrm{l}$. The stimuli mentioned were infused for periods of 30 minutes. After 15 minutes of stimulation Haloperidol at a concentration of $10^{-5} \mathrm{~mol} / \mathrm{l}$ was added for 8 minutes.

As can be seen in Figure 3 (left part) illustrating a representative experiment, Haloperidol powerfully suppressed the stimulated insulin and glucagon release. Upon termination of the Haloperidol infusion the concentration of hormones returned to control values after a short overshoot. Hormone release fell to prestimulatory levels when the infusions of secretagogues were stopped. Figure 4 shows the mean results \pm SEM from 5 experiments. The percentage hormone release during Haloperidol infusion is calculated on the basis of total glucagon and insulin release in the presence of the stimulus.

\section{Effect of Haloperidol upon the Secretion of Insulin and Glucagon at High $(6.3 \mathrm{mmol} / \mathrm{l}$ and $8.8 \mathrm{mmol} / \mathrm{l})$} Calcium Concentrations

To investigate a possible Haloperidol/calcium interrelationship for insulin and glucagon release a similar protocol was used. At a glucose concentration of $75 \mathrm{mg} / 100 \mathrm{ml}$ both hormones were stimulated when calcium concentration was increased from 1.3 to $8.8 \mathrm{mmol} / \mathrm{l}$ (Fig. 3, right part). At this high calcium concentration no significant inhibition of either insulin or glucagon were obtained during Haloperidol infusion. A short-lived off-response appeared after withdrawal of Haloperidol possibly due to oscillations in calcium influx. Similarly, in the presence of a calcium concentration of $6.3 \mathrm{mmol} / 1$ (Fig. 4) Haloperidol was unable to inhibit glucagon secretion sig-
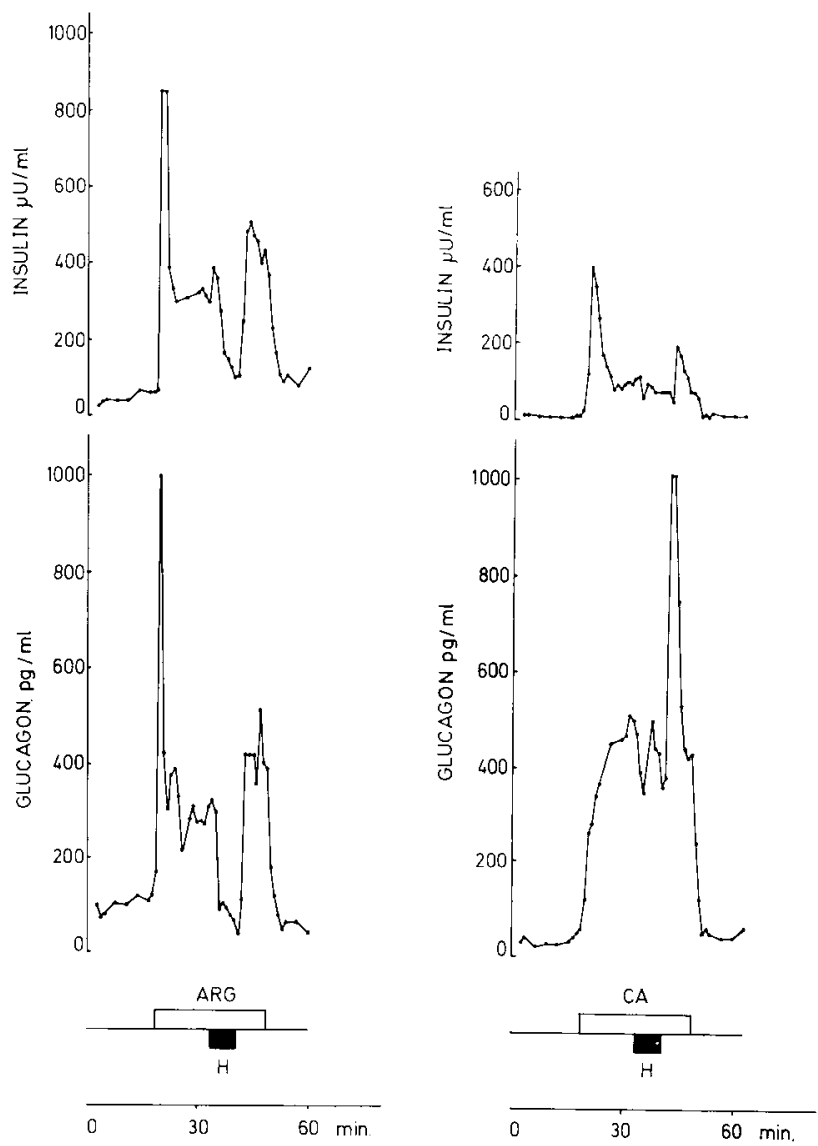

Fig. 3. Left part: Effect of Haloperidol $(\mathrm{H})\left(10^{-5} \mathrm{~mol} / \mathrm{l}\right)$ on arginine $(5 \mathrm{mmol} / \mathrm{l})$ stimulated insulin and glucagon secretion in the presence of a glucose concentration of $75 \mathrm{mg} / 100 \mathrm{~mL}$. A similar pattern was seen when isoproterenol and acetylcholine were given. Right part: Effect of Haloperidol $(\mathrm{H})\left(10^{-5} \mathrm{~mol} / \mathrm{l}\right)$ on insulin and glucagon secretion stimulated by high calcium $(8.8 \mathrm{mmol} / \mathrm{l})$. The glucose concentration was $75 \mathrm{mg} / 100 \mathrm{ml}$. A representative experiment out of five 


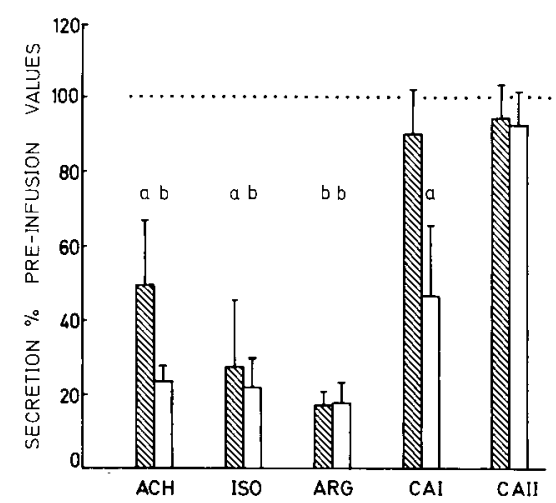

Fig. 4. A comparison of the inhibitory effect of Haloperidol $\left(10^{-5} \mathrm{~mol} / \mathrm{l}\right)$ on secretion of insulin and glucagon when stimulated by $1 \mu \mathrm{mol} / 1$ acetylcholine (ACH: $23 \%$ and $45 \%$ ), $2 \mathrm{ng} / \mathrm{ml}$ isoproterenol (ISO: $22 \%$ and $27 \%$ ), $5 \mathrm{mmol} / \mathrm{l}$ arginine (ARG: $18 \%$ and 17\%), $6.3 \mathrm{mmol} / 1$ calcium (CA I: $47 \%$ and $90 \%$ ) and $8.8 \mathrm{mmol} / \mathrm{l}$ calcium (CA II: $93 \%$ and $94 \%$ ). The glucose concentration was $75 \mathrm{mg} / 100 \mathrm{ml}$. Means of hormone release values during the last $5 \mathrm{~min}$ of the $8 \mathrm{~min}$ Haloperidol infusion are expressed in per cent of means of the levels during the 5 minutes preceding addition of the inhibitor. Insulin is depicted as open and glucagon as hatched columns. SEM of 5 experiments are shown as bars. a and $b$ represent statistical significant inhibition of the stimulated hormone release. a. 2 p $<0.05$ and b. 2 p $<0.001$

nificantly. However, at $6.3 \mathrm{mmol} / 1$ calcium concentration insulin secretion was decreased somewhat by addition of Haloperidol $(2 \mathrm{p}<0.05)$.

\section{Discussion}

In this study it has been shown that: 1) Haloperidol inhibits the release of insulin and glucagon dosedependently, and this is an immediate and reversible phenomenon; 2) Haloperidol inhibits release of both hormones when stimulated by isoproterenol, acetylcholine and arginine; and 3) the inhibitory action of haloperidol is counteracted by an increase in calcium concentration.

Previous studies have shown that dopamine inhibits insulin release [11] and as we ourselves had found that Haloperidol exaggerates the dopamine induced inhibition of insulin secretion (unpublished results) it seemed unlikely that Haloperidol should act as a dopaminergic antagonist in the endocrine pancreas.

However, Feldman et al. [12] have reported results which are at variance with our data with respect to the effect of Haloperidol on insulin release. They did not find any effect on glucose stimulated insulin release at a Haloperidol concentration of $10^{-4} \mathrm{~mol} / 1$. The reason for the divergence in results may be due to lesser responsiveness of their preparation consisting of slices of rabbit pancreas.
However, a species difference or a difference in calcium levels in the media might be an alternative explanation. There are no further reports on the influence of Haloperidol on hormone release from the pancreas in vitro.

The present data indicate that calcium antagonises the inhibitory effect of Haloperidol on insulin and glucagon secretion. These findings are consistent with the observations of Seeman et al. [13] who found that Haloperidol inhibits neurosecretion and that the inhibition of the neurosecretion could be elevated by high calcium concentrations. Like other potent neuroleptics which are very lipophilic, Haloperidol binds reversibly with various membrane structures, expands membranes and competes with calcium for binding sites on the cell membrane in muscles and nerves [14]. It is tempting to postulate that Haloperidol acts directly on the endocrine pancreatic islet cells by displacing membrane-bound calcium in a manner analogous to its effect in muscle and nerve. This could explain in part the inhibitory effect of Haloperidol on hormone secretion from the endocrine pancreas since calcium is known to play a key-role in the secretion of insulin $[15,16]$ and glucagon $[17,18]$. The dissociation between the inhibitory effect of Haloperidol on calcium-stimulated insulin and glucagon secretion observed in this report possibly represents a quantitative difference in the sensitivity of the pancreatic A and B cells to Haloperidol.

Using the isolated rat soleus muscle [19] Clausen (personal communication) found that Haloperidol is also a potent inhibitor of sodium flux across the cell membrane resulting in a decreased intracellular sodium concentration. Thus the decreased pancreatic hormone release observed during Haloperidol infusion may be ascribed partly to a decreased intracellular sodium concentration which secondarily leads to a fall in cytosolic calcium [20].

That the effect of calcium on Haloperidol action is not merely a function of generally increased secretion of insulin and glucagon is supported by the findings that other secretagogues for insulin and glucagon such as isoproterenol, arginine, and acetylcholine fail to overcome the inhibitory effect of Haloperidol.

It is of interest to note that Haloperidol influences the pancreatic hormone secretion in a somatostatin-like manner. The inhibitory action of somatostatin is also not restricted to basal conditions but includes pancreatic hormone secretion evoked by arginine [21, 22], isoproterenol [21], and acetylcholine [23]. Further, it has been observed that increasing calcium concentration counteracts the inhibitory effect of somatostatin [22, 24, 25]. Whether somatostatin and Haloperidol exert their 
inhibitory action at the same step in the secretion process remains, however, unclear.

In conclusion, it is suggested that Haloperidol inhibits insulin and glucagon release by blocking a step in the stimulus-secretion coupling probably by interfering directly and/or indirectly with calcium handling by pancreatic $\mathrm{A}$ and $\mathrm{B}$ cells.

Acknowledgements. I am very grateful to Mrs Karen Just, Mrs Inge Ploug and Mrs Birthe Videbæk for most conscientious and skilful technical assistance, and to Mrs Regitse Dahl for her expert assistance in typing the manuscript.

The study was supported by grants from Danish Medical Research Council (J. 512-8374) and NOVO Research Laboratories.

\section{References}

1. Falck, B., Hellman, B.: Evidence for the presence of biogenic amines in pancreatic islets. Experientia 19, 139-140 (1963)

2. Falck, B., Hellman, B.: A fluorescent reaction for monoamines in the insulin producing cells of the guinea-pig. Acta Endocrinol. (Kbh) 45, 133-138 (1964)

3. Cegrell, L., Falck, B., Hellman, B.: Monoaminergic mechanisms in the endocrine pancreas. In: S. E. Brolin, B. Hellman, H. Knutzon (Eds.): The structure and metabolism of the pancreatic islets, 429-435. Oxford: Pergamon Press 1964

4. Cegrell, L.: Monoamine-containing cells in the fetal and newborn guinea-pig pancreas. Life Sci. 6, 1647-1652 (1967)

5. Rossum, J.M. van: The significance of dopamine receptor blockade for the mechanism of action of neuroleptic drugs. Arch. Int. Pharmacodyn. Ther. 160, 492-494 (1966)

6. Furuta, Y., Hashimoto, K., Iwatsuki, K., Takeuchi, O.: Effects of enzyme inhibitors of catecholamine metabolism and haloperidol on the pancreatic secretion induced by L-DOPA and by dopamine in dogs. Br. J. Pharmacol. 47, 77-84 (1973)

7. Yeh, B.K., McNay, J.L., Goldberg, L. I.: Attenuation of dopamine renal and mesenteric vasodilatation by haloperidol: evidence for a specific dopamine receptor. J. Pharmacol. Exp. Ther. 168, 303-309 (1969)

8. Iversen, J., Miles, D. W.: Evidence for a feed-back inhibition of insulin on insulin secretion in the isolated, perfused canine pancreas. Diabetes 20, 1-9 (1971)

9. Iversen, J.: Secretion of glucagon from the isolated, perfused canine pancreas. J. Clin. Invest. 50, 2123-2136 (1971)

10. Ørskov, H., Thomsen, H. G., Yde, H.: Wick chromatography for rapid and reliable immunoassay of insulin, glucagon and growth hormone. Nature 219, 193-195 (1968)

11. Quickel, K. E., Feldman, J. M., Lebovitz, H. E.: Inhibition of insulin secretion by serotonin and dopamine: Species variation. Endocrinology 89, 1295-1302 (1971)
12. Feldman, J. M., Quickel, K. E., Lebovitz, H. E.: Potentiation of insulin secretion in vitro by serotonin antagonists. Diabetes 21, 779-788 (1972)

13. Seeman, P., Lee, T.: Antipsychotic drugs: Direct correlation between clinical potency and presynaptic action on dopamine neurons. Science 188, 1217-1219 (1975)

14. Seeman, P.: The membrane actions of anesthetics and transquilizers. Pharmacol. Rev. 24, 583-655 (1972)

15. Milner, R. D. G., Hales, C. N.: The role of calcium and magnesium in insulin secretion from rabbit pancreas studied in vitro. Diabetologia 3, 47-49 (1967)

16. Grodsky, G. M., Bennett, L. L.: Cation requirements for insulin secretion in the isolated, perfused pancreas, Diabetes $\mathbf{1 5}$, 910-913 (1966)

17. Iversen, J., Hermansen, K.: Calcium, glucose and glucagon release. Diabetologia 13, 297-303 (1977)

18. Hermansen, K., Iversen, J.: Effect of verapamil on pancreatic glucagon release from the isolated, perfused canine pancreas. Scand. J. Clin. Lab. Invest. 37, 139-142 (1977)

19. Dahl-Hansen, A. B., Clausen, T.: The effect of membrane stabilizers and ouabain on the transport of $\mathrm{Na}^{+}$and $\mathrm{K}^{+}$in rat soleus muscle. Biochim. Biophys. Acta 318, 147-153 (1973)

20. Donatsch, P., Lowe, D. A., Richardson, B. P., Taylor, P.: The functional significance of sodium channels in pancreatic betacell membranes. J. Physiol. (Lond.) 267, 357-376 (1977)

21. Gerich, J. E., Lovinger, R., Grodsky, G. M.: Inhibition by somatostatin of glucagon and insulin release from the perfused rat pancreas in response to arginine, isoproterenol and theophylline: Evidence for a preferential effect on glucagon secretion. Endocrinology 96, 749-754 (1975)

22. Bhathena, S. J., Perrino, P. V., Voyles, N. R., Smith, S. S., Wilkins, S. D., Coy, D. H., Schally, A. V., Recant, L.: Reversal of somatostatin inhibition of insulin and glucagon secretion. Diabetes 25, 1031-1040 (1976)

23. Iversen, J.: Further characterization of the inhibitory effect of somatostatin on insulin and glucagon release from the isolated, perfused canine pancreas. Diabetologia 11, 352 (1975)

24. Curry, D. L., Bennett, L. L.: Reversal of somatostatin inhibition of insulin secretion by calcium. Biochem. Biophys. Res. Commun. 60, 1015-1019 (1974)

25. Taminato, T., Seino, Y., Goto, Y., Imura, H.: Interaction of somatostatin and calcium in regulating insulin release from isolated pancreatic islets of rats. Biochem. Biophys. Res. Commun. 66, 928-934 (1975)

Received: March 23, 1978,

and in revised form: June 9, 1978

Dr. K. Hermansen

Second University Clinic of Internal Medicine

Kommunehospitalet

DK-8000 Aarhus C

Denmark 